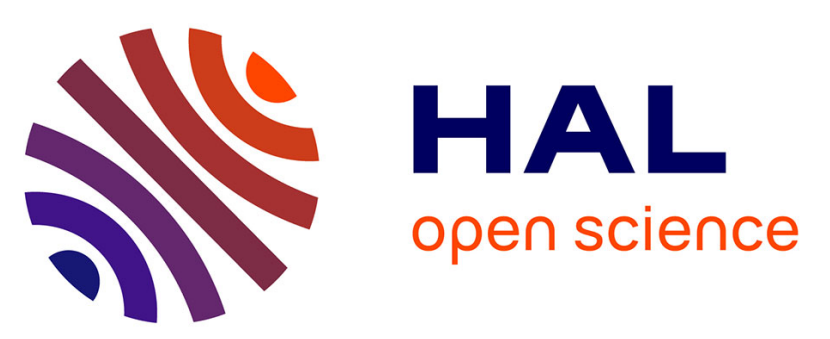

\title{
Erratum: Ultrasonic study of the shear mechanical impedance of butyloxybenzylidene octylaniline near the crystalline-B-smectic-A phase transition Y. Thiriet, P. Martinoty
}

\section{- To cite this version:}

Y. Thiriet, P. Martinoty. Erratum: Ultrasonic study of the shear mechanical impedance of butyloxybenzylidene octylaniline near the crystalline-B-smectic-A phase transition. Journal de Physique Lettres, 1982, 43 (21), pp.762-762. 10.1051/jphyslet:019820043021076200 . jpa-00232122

HAL Id: jpa-00232122

https://hal.science/jpa-00232122

Submitted on 1 Jan 1982

HAL is a multi-disciplinary open access archive for the deposit and dissemination of scientific research documents, whether they are published or not. The documents may come from teaching and research institutions in France or abroad, or from public or private research centers.
L'archive ouverte pluridisciplinaire HAL, est destinée au dépôt et à la diffusion de documents scientifiques de niveau recherche, publiés ou non, émanant des établissements d'enseignement et de recherche français ou étrangers, des laboratoires publics ou privés. 


\section{Erratum}

Ultrasonic study of the shear mechanical impedance of butyloxybenzylidene octylaniline near the crystalline-B-smectic-A phase transition

Y. ThiriEt and P. MARTINOTY

(J. Physique-Lett. 43 (1982) L-137 - L-145)

Page L-144, lines 11-12, the sentence :

«... of the order of $0.7^{\circ} \mathrm{C}$ determined by X-ray techniques [17]. "

should be replaced by :

«... of the order of $0.7^{\circ} \mathrm{C}$, instead of $0.3^{\circ} \mathrm{C}$ determined by X-ray techniques [17]. » 